\title{
Drawing Positive Lessons From the Presence of 'The Social' Outside of EU Social Policy Stricto Sensu
}

\author{
Elise Muir*
}

Treaty obligations: the EU shall combat social exclusion and discrimination, and promote social justice and protection - EU institutions responses to social challenges outside of the Social Policy Title - Fragmentation of Social Policy: in many ways deeply unsatisfactory, yet useful lessons may be learnt - Social implications of economic integration - Rethinking EU intervention on the protection of individuals owing to a fundamental rights' narrative.

\section{INTRODUCTION}

EU social policy has been rather static, if not almost paralysed, over the past few years. ${ }^{1}$ Most Directives adopted in fields covered by today's version of the Title on 'Social Policy' in the Treaty on the Functioning of the European Union (the 'Social Policy Title') date back from the pre-Amsterdam period and have at best been re-casted in the early 2000s. ${ }^{2}$ Attempts to more profoundly reform the field, for instance in relation to working time or maternity leave, have stalled. ${ }^{3}$ Yet, it

* Professor for European Law and Head of the Institute for European Law at the KU Leuven. I am very grateful to Claire Kilpatrick for most valuable comments on an early draft, as well as to Caterina Molinari for very useful research assistance. The usual disclaimer naturally applies.

${ }^{1}$ Note that one may hope for change as a follow up of the Commission large scale impulse: Commission staff working document accompanying the document communication from the Commission to the European parliament, the Council, the European and Social Committee and the Committee of the regions 'Establishing a European Pillar of Social Rights' (SWD/2017/201).

${ }^{2}$ Examples of recast include: Directive 2003/88 concerning certain aspects of the organisation of working time (OJ L 299, 18.11.2003, p. 9-19) and Directive 2006/54 on the implementation of the principle of equal opportunities and equal treatment of men and women in matters of employment and occupation (OJ L 204, 26.7.2006, p. 23-36).

${ }^{3}$ See, for example, Proposal for a Directive amending Directive 2003/88/EC concerning certain aspects of the organisation of working time, $\operatorname{COM}(2004) 607$ final; and Proposal for a Directive 
cannot be denied that the social question has been present or surfaced, at times very forcefully, in a multitude of other fora in recent years. Contributions to this Special Issue mostly delve into the problems created by this asymmetry. In contrast, on invitation by Claire Kilpatrick, this article investigates what aspects of the presence of social questions outside of the Title of 'Social Policy' may be deemed to be 'positive'?

It will come as no surprise that a Special Issue on the displacement of Social Europe understands 'positive' through a normative lens. A first use of the term indeed amounts to assessing the substance of rules. In this context and for the purpose of this paper, 'positive' refers to where EU law allows States to maintain a high level of protection or encourages and requires them to upgrade existing standards. There may however be a second use of the expression 'positive' in the context of a discussion on EU law. A more institutional approach turns to the process by which decisions on social questions are made at EU level. One may indeed read 'positive' as requiring a conscious political decision at European level to tackle social questions. ${ }^{4}$ Both the normative and the institutional lenses lead to a common observation: the main added value of investigating social questions addressed outside of EU social policy stricto sensu comes precisely from the fact that mechanisms provided outside of the Social Policy Title have been used to enhance social standards though explicit political choices.

This assertion may seem somewhat counterintuitive, as one could assume that the lack of dynamism of EU social policy stricto sensu necessarily results in the absence of progress for social questions. Yet, as social concerns have become more visible across various forms and areas of EU intervention and as the Social Policy Title proved too difficult to use due to lack of the necessary political support, EU institutions have developed responses to social challenges outside of the Social Policy Title. Such fragmentation is in many ways deeply unsatisfactory. The range and level of protection are insufficient; furthermore, the political message on how the EU addresses social questions is unclear, as forcefully explained by other contributors to this issue. In the meantime, useful lessons may still be inferred from a close examination of the tools used and of the outcomes reached. These may provide fruitful sources of inspiration to think about the future of Social Europe.

amending Directive $92 / 85$ on the introduction of measures to encourage improvements in the safety and health at work of pregnant workers and workers who have recently given birth or are breastfeeding, $\operatorname{COM}(2008) 637$ final.

${ }^{4}$ See further M. Blauberger, 'From Negative to Positive Integration? European State Aid Control Through Soft and Hard Law', (2008) MPIfG Discussion Paper 08/4, Cologne: Max Planck Institute for the Study of Societies and F.W. Scharpf 'Negative and Positive Integration' in F.W. Scharpf, Governing in Europe: Effective and Democratic? (Oxford University Press 1999) p. 43. 
With a view to elaborating further on responses to social concerns located outside on EU social policy stricto sensu, the article builds on two preliminary assumptions. Firstly, EU social policy to date is commonly understood as providing for a set of minimum standards of worker protection. A reflection on how social questions are addressed outside of the Social Policy Title of the TFEU though ought to take a broader perspective. To that effect, our starting point is paragraph 2 of Article 3(3) TEU, according to which the EU shall in essence 'combat social exclusion and discrimination, and [...] promote social justice and protection'. As we shall see, several instruments adopted outside of the Social Policy Title contribute to these central social objectives even though they may not be specifically related to employment. ${ }^{5}$ Secondly, to look at the presence of social questions through this uncommon yet positive lens, one may not reason in binary terms seeing economic integration and social protection, or antidiscrimination and social rights, or again European and State intervention as mutually exclusive. Instead, one ought to look at the process of European integration as profoundly reflexive and constantly inviting a reconsideration of pre-established parameters.

One may agree or disagree with these preliminary assumptions, but in taking them as a starting point, it becomes possible to engage in a constructive analysis of the social implications of economic integration as well as fundamental rights law and policy making in the EU. These two areas of EU law have been the main driving forces of social debate on EU affairs over the past decades. It will be argued that the broad acknowledgment of the possible positive incidental impact of EU economic law and governance on social values outside of the traditional social acquis invites us to rethink both the political opportunities that the EU may offer to advance social rights and the relationship between EU economic and domestic social policies. Furthermore, the switch to a fundamental right narrative, with an explicit focus on key social questions, invites us to broaden our understanding of the EU's duty to protect individuals, as well as to develop a new range of techniques for that purpose.

\section{Chasing SOCIAL EUROPE OUTSIDE OF THE TRADITIONAL SOCIAL ACQUiS}

The overall recognition of the incidental impact of EU law-making on social values is the first sign of the presence of 'the social' outside the scope of the Social Policy Title. The effects of EU intervention on social values do indeed often occur outside

\footnotetext{
${ }^{5}$ With a different approach: Hilpold identifies 'islands of solidarity' such as cohesion policy, development assistance asylum policy, EMU: P. Hilpold, 'Understanding solidarity within EU Law: an analysis of the "Islands of solidarity" with peculiar regard to monetary union', 34(1) Yearbook of European Law (2015) p. 257 at p. 264.
} 
of EU social policy and can be very explicit even when this is not the main objective pursued in the decision-making process. Without seeking to be exhaustive, it is useful to map out a set of general trends through which these phenomena take place. Responses to the incidental impact on social values present two main advantages. The inherently social dimension of the process of European integration across its various policy fields, in particular in the economic field, creates significant potential for advocacy and social progress, as will be illustrated. Reactions to such an incidental impact also shed light on current re-adjustments in the relationship between the EU and the Member States with a view to protecting national social settlements from EU law.

\section{Acknowledging the potential for positive incidental impacts of EU law on social values}

The incidental impact of EU law-making on social values results from age-old debates on the social dimension of EU internal market-making as well as, more recently, from increasingly structured attempts to mainstream social concerns across multiple areas of EU intervention.

\section{Social values and free movement}

European integration carried through EU free movement law may have a direct and positive impact on social protection. This is not to deny that market integration also has detrimental effects on 'the social', merely to recall that it may not only have detrimental effects and thus open the floor for reflection on the interplay between market making and social policy concerns. At the outset, it may be recalled that according to a well-established narrative, positive effects may be expected to result from successful economic integration, leading to higher employment rates and social progress as hoped for by the member states and expressed in paragraph 1 of Article 3(3) TEU. The market and the social may also be reconciled to the extent that the rules on free movement liberate individual actors and empower them to seek improvement of their status elsewhere. These points will not be further debated as they are common elements of the discussion on the social dimension of the process of European integration. $^{6}$

Besides the classic two-fold meta arguments just exposed, it is possible to look for positive effects of EU free movement rules on social value through alternative routes. To start with, EU internal market legislation often regulates non-economic values thereby providing a baseline for protection across the EU. ${ }^{7}$ In that case, social objectives are interwoven in an internal market narrative that drives the

${ }^{6}$ E.g. O. Gerstenberg, 'The justiciability of Socio-economic Rights, European solidarity, and the role of the Court of Justice of the EU', 33(4) YEL (2014) p. 245 at p. 270.

${ }^{7}$ V. Kosta, Fundamental Rights in EU Internal Market Legislation (Hart 2015). 
legislative process forward. Importantly, the level of protection thereby requested is not necessarily the lowest common denominator across the member states; it may be higher. ${ }^{8}$ This observation is far from new. Several of the Directives ${ }^{9}$ that today form the bulk of the EU social acquis in fact originated in internal market making and had as a legal basis the early equivalent of either today's Articles 114 and 115 TFEU (internal market) ${ }^{10}$ or an earlier version of the flexibility clause (now Article $352 \mathrm{TFEU})^{11}$ that allowed the adoption of 'action ... necessary to attain, in the course of the operation of the common market, one of the objectives of the Community'. ${ }^{12}$

Locating the social within the market also has considerable potential when one examines the external relations of the EU. The EU may step up international commitments to selected social standards, as exemplified by accession to the United Nations Convention on Rights of Persons with Disabilities, ${ }^{13}$ or by the Commission proposal for the conclusion of the Marrakech Treaty to Facilitate Access to Published Works for Persons Who Are Blind, Visually Impaired or Otherwise Print Disabled. ${ }^{14}$ The EU's involvement in such international agreements is (partly) based on an internal market and trade rationale and legal bases for the adoption of internal market legislation are indeed used (e.g. Article 114 TFEU). Such external commitments may in turn support internal policy change with an upgrade of social standards, as suggested by the proposals for an

${ }^{8}$ Ibid., p. $242-45$.

${ }^{9}$ For a fuller account see G. De Baere and K. Gutman, 'The Basis in EU Constitutional Law for Further Social Integration', in C. Barnard et al. (eds.), A European Social Union after the Crisis (Cambridge University Press 2017) p. 356 ff.

${ }^{10}$ E.g. Directive 2001/23 on the approximation of the laws of the Member States relating to the safeguarding of employees' rights in the event of transfers of undertakings, businesses or parts of undertakings or businesses (OJ L 82, 22.3.2001, p. 16-20), adopted on the basis of the former Art. 94 TEC.

${ }^{11}$ On the use of the legal bases for social objectives see De Baere and Gutman, supra n. 10, p. $352 \mathrm{ff}$.

${ }^{12}$ Art. 235 TEEC. E.g. Directive 76/207 on the implementation of the principle of equal treatment for men and women as regards access to employment, vocational training and promotion, and working conditions (OJ L 39, 14.2.1976, p. 40-42) was adopted on that basis.

${ }^{13}$ Convention on the Rights of Persons with Disabilities (adopted on 24 January 2007) A/RES/ 61/106, available at <www.wipo.int/wipolex/en/other_treaties/text.jsp?file_id $=191300>$, visited 27 December 2017. Decision concerning the conclusion, by the European Community, of the United Nations Convention on the Rights of Persons with Disabilities (OJ L 23, 27.1.2010, p. 35-36).

${ }^{14}$ Text available at <www.wipo.int/wipolex/en/details.jsp?id=13169>, visited 27 December 2017. Proposal for a Decision on the conclusion, on behalf of the European Union, of the Marrakesh Treaty to Facilitate Access to Published Works for Persons who are Blind, Visually Impaired, or Otherwise Print Disabled, COM(2014)638. See also CJEU Opinion 3/15 EU: C:2017:114; and Opinion of AG Wahl in Opinion Procedure 3/15, EU:C:2016:657. 
Accessibility Act ${ }^{15}$ as well as the freshly adopted Directive on certain permitted uses of certain works and other subject matter protected by copyright and related rights for the benefit of persons who are blind, visually impaired or otherwise print-disabled. ${ }^{16}$ Each of them is directly related to the two international agreements just mentioned. ${ }^{17}$

An interesting aspect of the social dimension of EU free movement law lies in the way that political decision-making on free movement seeks to fence EU free movement law off or away from domestic social policies. EU legal intervention on free movement matters may indeed seek to clearly protect certain areas of domestic policy against EU intervention. Topical examples of this are the provisions of Directive 2004/38 on the free movement of EU citizens ${ }^{18}$ ('Citizenship Directive') that seek to protect domestic social assistance systems against unreasonable burdens. ${ }^{19}$ Recent case law of the European Court of Justice on these provisions suggests that we may be looking at a trend towards re-asserting the social dimension of member states' sovereign contribution to the EU legal order. ${ }^{20}$

The Court can indeed be understood as having sharpened the distinction between economic actors and non-economic actors within the meaning of the Citizenship Directive. In recent years, as confirmed in Alimanovic, the Court has emphasised that EU citizens' right to reside in a member state other than the one from which they hold nationality depends on the conditions listed in Article 7 of Directive 2004/78. ${ }^{21}$ According to that article, if a person does not have an economic activity, is not a student or a family member, then one shall:

have sufficient resources for themselves and their family members not to become a burden on the social assistance system of the host Member State during their period

${ }^{15}$ European Commission, Proposal for a Directive of the European Parliament and of the Council on the approximation of the laws, regulations and administrative provisions of the Member States as regards the accessibility requirements for products and services (COM (2015)615).

${ }^{16}$ Directive 2017/1564 on certain permitted uses of certain works and other subject matter protected by copyright and related rights for the benefit of persons who are blind, visually impaired or otherwise print-disabled and amending Directive 2001/29 on the harmonisation of certain aspects of copyright and related rights in the information society (not yet in force, OJ L 242, 20.9.2017, p. 6-13).

${ }^{17}$ See further L. Waddington, 'The European Union and the United Nations Convention on the Rights of Persons with Disabilities: A story of Exclusive and Shared Competences', 18(4) Maastricht Journal of European and Comparative Law (2011) p. 431.

${ }^{18}$ Directive $2004 / 38$ on the right of citizens of the Union and their family members to move and reside freely within the territory of the Member States amending Regulation 1612/68 and repealing Directives 64/221, 68/360, 72/194, 73/148, 75/34, 75/35, 90/364, 90/365 and 93/96 (OJ L 158, 30.4.2004, p. 77-123).

${ }^{19}$ See recitals (10) and (16) as interpreted by the ECJ in Case C-333/13, Dano, EU:C:2014:2358.

${ }^{20} \mathrm{I}$ am grateful to C. Kilpatrick for suggesting this expression.

${ }^{21}$ ECJ 15 September 2015, Case C-67/14, Alimanovic, ECLI:EU:C:2015:597, paras. 51-53. 
of residence and have comprehensive sickness insurance cover in the host Member State. ${ }^{22}$

This aspect of the Citizenship Directive is now understood by the Court as drawing the line between the residence rights of EU citizens in other member states and the member states' control of their social assistance systems. ${ }^{23}$ Earlier rulings of the Court of Justice had engineered citizenship rights directly enshrined in Treaty provisions. These Treaty based rulings, starting from Martinez Sala,${ }^{24}$ were protective of mobile and vulnerable EU citizens but drew a rather unclear line between free movement rights and domestic control of social assistance systems.

The recent focus of the Court on treating Article 7(b) of the Citizenship Directive as a gateway to EU citizenship rights for non-economic actors might, to the understandable disappointment for the actual claimants, ${ }^{25}$ be read as re-locating or re-empowering domestic authorities to shape the contours of their social assistance system. It remains to be seen whether this form of displacement, from the EU to the national level, is to be welcomed since free movement and its impact on domestic social system is much debated. In any case, this approach largely de-constitutionalises EU citizenship law - and the social question within it - thus aligning the case law of the Court of Justice on political guidance ${ }^{26}$ and relying on the explicit gradation enshrined in secondary law to clarify the relationship between EU and national law in the field.

\section{Mainstreaming social questions throughout EU law}

Mainstreaming constitutes a more recent and most important way of 'injecting the social' across all EU policies. Social values and rights indeed figure prominently as subjects of mainstreaming in the provisions of the TFEU having general application, ${ }^{27}$ especially since the Lisbon Treaty. The Union is expected to eliminate inequalities, and to promote equality between men and women in all its activities (Article 8 TFEU). The Union shall also take into account requirements

${ }^{22}$ Directive 2004/38, Art. 7(b).

${ }^{23}$ ECJ 11 November 2014, Case C-333/13, Dano, EU:C:2014:2358, paras. 74-79.

${ }^{24}$ ECJ 12 May 1998, Case C-85/96, Martínez Sala, EU:C:1998:217, paras. 60-63.

${ }^{25}$ See C. O'Brien, 'An Insubstantial Pageant Fading: A Vision of EU Citizenship under the AG's Opinion in C-308/14 Commission v UK', EU Law Analysis, 7 October 2015, available at < eulawanalysis.blogspot.be/2015/10/an-insubstantial-pageant-fading-vision.html >, visited 27 December 2017.

${ }^{26}$ Although admittedly within the limited parameters of EU decision-making processes: see M. Dawson, 'The political face of judicial activism: Europe's law-politics imbalance', in M. Dawson, et al. (eds.), Judicial Activism at the European Court of Justice (Edward Elgar 2013).

${ }^{27}$ Part one, Title II TFEU. 
linked to the promotion of a high level of employment, the guarantee of adequate social protection, the fight against social exclusion, and a high level of education, training and protection of human health when defining and implementing its policies and activities (Article 9 TFEU). The Union shall further aim to combat discrimination based on sex, racial or ethnic origin, religion or belief, disability, age or sexual orientation (Article 10 TFEU).

In practice, one way of giving flesh to the duty to mainstream is through impact assessments by which the Commission examines if there is need for EU action as well as the possible impacts of existing options when preparing for the adoption of EU measures. ${ }^{28}$ The Commission has issued 'Guidance for assessing Social Impacts within the Commission Impact Assessment system' which date back to 2009. ${ }^{29}$ There is also 'Operational Guidance on taking account of Fundamental Rights in Commission Impact Assessments' from 2011. ${ }^{30}$ Unfortunately the Court of Auditors' evaluation of the impact assessment system dates back to 2010 and was based on data from 2003-2008, thus before the economic and financial crisis that created multiple challenges for Social Europe. In reality, it may be difficult to evaluate the positive effects of these impact assessments for non-economic rights or values, either because of the difficulty of quantifying social well-being ${ }^{31}$ or because of weaknesses in the very structure of impact assessment procedures. ${ }^{32}$ Yet, one could for instance hope for more detailed guidance on how to make 'social-or-fundamental-right-proof ${ }^{33}$ specific sectors of EU activities ${ }^{34}$ as well as better training of actors involved in the decision-making process such as Commission civil servants. ${ }^{35}$ One may also hope for an update of the way to address social challenges since the 2009 Social Impact Assessment Guidance mentioned above was issued in the early stages of the economic and financial crisis.

A second way of implementing the duty to mainstream may be found in what has been described as the 'socialisation' of the European Semester which follows

\footnotetext{
${ }^{28}$ Illustrating the importance of impact assessment for the work of other EU institutions: Interinstitutional Agreement between the European Parliament, the Council of the European Union and the European Commission on Better Law-Making (OJ L 123, 12.5.2016, p. 1-14).

${ }^{29}$ Available at <ec.europa.eu/smart-regulation/impact/key_docs/docs/guidance_for_assessing_ social_impacts.pdf $>$, visited 27 December 2017.

${ }^{30}$ Available at <ec.europa.eu/smart-regulation/impact/key_docs/docs/sec_2011_0567_en.pdf >, visited 27 December 2017.

${ }^{31}$ M. Dawson, 'Better regulation and the future of EU regulatory law and politics', 53 CMLR (2016) p. 1209 at p. 1124.

${ }^{32}$ I. De Jesús Butler, 'Ensuring Compliance with the Charter of Fundamental Rights in Legislative Drafting: The Practice of the European Commission', 37 EL Rev (2012) p. 397 at p. 405.

${ }^{33}$ I am grateful to C. Kilpatrick for suggesting this expression.

${ }^{34}$ De Jesús Butler, supra n. 33, p. 414-415.

${ }^{35}$ The author is grateful to an anonymous reviewer for useful suggestions on this point.
} 
upon the commitment of Commission President Juncker to enhance the social dimension of European governance. ${ }^{36}$ In recent research, Zeitlin and Vanhercke point at the "partial but progressive "socialisation" of the European Semester ${ }^{37}$ and thus the mainstreaming of social policy concerns in the process of economic governance $^{38}$ The authors suggest that these efforts have allowed social policy makers to influence economic policy actors and lead to internalisation of social concerns by economic policy actors. ${ }^{39}$ This positive assessment of the socialisation of the Semester may not be as uncontroversial as it seems, as pointed out by Dawson. ${ }^{40}$ Yet, there overall seems to have been some progress towards the socialisation of economic governance. For instance, Country Specific Recommendations issued in the context of the European Semester are now adopted on the dual legal bases of Articles 121(2) (economic policy) and 148(4) TFEU (employment policy) so as to involve persons responsible for employment and social policy in the decision-making process.

A third form of mainstreaming operates in EU external relations as called for by Article 21 TEU read in conjunction with Article 205 TFEU. References to human rights and social standards are increasingly often present in external agreements such as trade agreements. ${ }^{41}$ Such practice has been assessed as 'successful in terms of the [EU's] obligation to conduct an ethical foreign policy. ${ }^{42}$ Further efforts in that direction are being called for, as illustrated by the Namur Declaration of 5 December $2016^{43}$ intended to further promote 'An EU-Values Driven Path to

${ }^{36}$ As illustrated with reference to the European pillar of social rights in Jean-Claude Juncker: 'State of the Union 2015: Time for Honesty, Unity and Solidarity' (Strasbourg, 9 September 2015).

${ }^{37}$ J. Zeitlin and B. Vanhercke, 'Socializing the European Semester: EU social and economic policy co-ordination in crisis and beyond', 25(2) Journal of European Public Policy (2018) p. 149, available at <dx.doi.org/10.1080/13501763.2017.1363269 >, visited 28 December 2017.

${ }^{38}$ Ibid., p. $19 \mathrm{ff}$.

${ }^{39}$ Ibid., p. 21.

${ }^{40}$ See M. Dawson, 'New governance and the displacement of Social Europe: the case of the European Semester', in this issue.

${ }^{41}$ E.g. Arts 13.1-13.11 of the EU-South Korea FTA (OJ L 127, 14.5.2011, p. 6). See also Arts 8.9(1), 10.2(5), 12.2(2),13.2(5), 22.1, 22.3, 23.1 and 23.3(2) of the Comprehensive Economic and Trade Agreement (CETA) between Canada, of the one part, and the European Union and its Member States, of the other part (OJ L 11, 14.1.2017, p. 23). See further R. Yotova 'Balancing Economic Objectives and Social Considerations in the New EU Investment Agreements: Commitments versus Realities', in Barnard et al., supra n. 10, p. 271. See also Regulation (EU) No 978/2012 of the European Parliament and of the Council of 25 October 2012 applying a scheme of generalised tariff preferences and repealing Council Regulation (EC) No 732/2008 (consolidated in 2017).

${ }^{42} \mathrm{~L}$. Bartels, 'Human rights and sustainable development: obligations in EU free trade agreements', 24 Legal Studies Research Paper Series (2012).

${ }^{43}$ Available at < www.declarationdenamur.eu/doc/NamurEN.pdf>, visited 28 December 2017. 
Negotiating and Concluding Economic and Trade Agreements', ${ }^{44}$ with emphasis being placed for instance on 'Public services and services of general interest, as defined in the Parties' respective legislation, [being] fully excluded from the scope of such treaties', as well as standstill clauses to prevent the Parties 'from lowering their social, sanitary and environmental norms to promote exports and attract investment. These clauses shall be matched with sanction mechanisms.' This approach amounts, once again, to protecting national social settlements from EU intervention, as will be further elaborated below.

\section{Making good use of the incidental effects of EU law on social values}

The phenomena identified above shall encourage those interested in Social Europe to pay attention to developments outside of the Social Policy Title of the TFEU. This is necessary not only to create awareness of the multitude of sparse signs of social progress but also, and perhaps more importantly, to reflect on lessons to be drawn from the relevant processes and outcomes.

\section{Political CONTESTATION AND ADVOCACY ON 'THE SOCIAL'}

Acknowledging the potential for positive - besides the negative - implications of economic law-making may stimulate political debate upstream of decision-making processes. In departing from a principled or binary approach to tensions between economic and social questions, channels for advocacy open up. The processes described in the past section may indeed offer many opportunities to seek to enhance the protection of given groups of individuals through carefully targeted political contestation or pressure. Decision-making at EU level in such a context creates possibilities for non-majoritarian political entrepreneurs (such as civil society organisations representing specific interests) to push for alternative agendas. ${ }^{45}$ In that context, what may be missing is more creativity on how to achieve social objectives incidentally through economic law making.

However, there already exist examples of advocacy intended to make use of the powerful infrastructures and driving forces of European economic law-making to convey social values and enhance individuals' protection. The work of Lisa Waddington on the link between the EU's internal market and the protection of

\footnotetext{
${ }^{44}$ D. Desierto, 'Namur Declaration of 5 December 2016: An EU-Values Driven Path to Negotiating and Concluding Economic and Trade Agreements', EJIL:Talk!, 7 December 2016, $<$ www.ejiltalk.org/namur-declaration-of-5-december-2016-an-eu-values-driven-path-to-negotiatingand-concluding-economic-and-trade-agreements/ >, visited 28 December 2017.

${ }^{45}$ P. De Wilde, 'Silencing the Eurocrats in public crisis politics', in D. Chalmers et al. (eds.), The End of the Eurocrats' Dream (Cambridge University Press 2016) p. 146 at p. 152.
} 
disabled persons illustrates this point forcefully. ${ }^{46}$ The pending Commission proposal for an Accessibility Act aiming at the approximation of the laws, regulations and administrative provisions of the member states as regards the accessibility requirements of products and services ${ }^{47}$ is a most useful example of what such an approach can lead to. In relation to more traditional areas of social policy, Catherine Barnard has also proposed to 'boldly go' for the incorporation of social clauses in public procurement requirements. ${ }^{48}$ She powerfully argues that this is made easier after the reform of EU public procurement law from 2014. The latter clarifies that it is of 'utmost importance to fully exploit the potential of public procurement to achieve the objectives of [...] sustainable and inclusive growth'. Among other things, the new legislation recalls the duty of the member states to take appropriate measures to ensure that public procurement complies with 'social and labour law established by Union law, national law, collective agreements or by the international environmental, social and labour law provisions listed in Annex X' ${ }^{49}$ A final example of such interesting advocacy is the call by the Social Platform to use the infrastructures of the European Semester to counter the current trend pushing member states to readjust wages downwards and the Commission's response in the European Pillar of Social Rights from 2017.50

Importantly, it is sometimes the denial of the presence of the 'social' in mainstream EU law and policy, or the refusal to locate the social outside of the narrow domain of EU social policy, that can constitute an obstacle to enhancing social protection. For instance, one may regret that the EU Justice scoreboard remains almost exclusively focused on EU economic law with hardly any information - or visibility of information - on access to justice in employment cases. In that example, an area of EU economic law develops without its social dimension being given visibility. Another example is where EU fundamental right

${ }^{46}$ L. Waddington, 'A Disabled Market: Free Movement of Goods and Services in the EU and Disability Accessibility', 15(5) European Law Journal (2009) p. 575.

${ }^{47}$ Proposal for a Directive on the approximation of the laws, regulations and administrative provisions of the Member States as regards the accessibility requirements for products and services, $\operatorname{COM}(2015) 615$. See comments such as A. Ahtonen and R. Pardo, 'The Accessibility Act - Using the single market to promote fundamental rights', (2013) Policy Brief-European Policy Centre.

${ }^{48}$ C. Barnard, 'To Boldly Go: Social Clauses in Public Procurement', 46(2) Industrial Law Journal (2017) p. 208. See also C. Tobler, 'Encore: "Women's Clauses" in public procurement under Community law', 25(6) European Law Review (2000) p. 618.

${ }^{49}$ E.g. Directive 2014/24 on public procurement and repealing Directive 2004/18 (OJ L 94, 28.3.2014, p. 65-242), Recital 95 and Art. 18(2). Indeed, Annex X provides for a list of international social and environmental conventions.

${ }^{50}$ See further, Social Platform, 'Position Paper on Minimum Wage' (26 February 2015), available at <www.socialplatform.org/> and Commission staff working document accompanying the document communication from the Commission to the European Parliament, the Council, the European and Social Committee and the Committee of the regions 'Establishing a European Pillar of Social Rights' (SWD/2017/201), on 'Wages'. 
bodies such as the Fundamental Rights Agency are not being invited to examine the possible implications of the economic crisis on fundamental rights. ${ }^{51}$ It has indeed been regretted that such a specialised agency has not been mandated to examine problems such as the impact of conditionality on vulnerable categories of the population (e.g. such as part-time workers and women). ${ }^{52}$

\section{Enhanced protection of national social settlements from EU law?}

Beyond acknowledging the incidental impact of EU law making on social values, the examples above illustrate the preliminary stages of a trend allowing for more deference to domestic social systems. The exclusion of EU intervention from certain areas of domestic social policies has long existed, as is exemplified by Article 153(5) TFEU, according to which the adoption of EU measures, as envisaged in Article 153(1) to 153(4) TFEU, is precluded with respect 'to pay, the right of association, the right to strike or the right to impose lock-outs'. Yet, recent developments suggest the emergence of increasingly institutionalized efforts towards retroceding space for domestic social spheres in general EU law making. The 'socialisation' of the European semester, introduced earlier, can in many ways be read as a withdrawal from the highly intrusive nature of European governance towards domestic social policies. ${ }^{53}$ Latest EU citizenship case law, as introduced above, may also be read as taking a step back from earlier rulings allowing mobile non-economically active EU citizens to receive social assistance in host states and clarifying the relationship between EU law and social settlements in that field. Whether this trend will be confirmed in the future remains to be seen. It could, for instance, be accompanied by stronger intervention at EU level to positively support these domestic social settlements and provide further steering on central questions in the context of the EU social policy stricto sensu. ${ }^{54}$

\section{RETHINKING EU INTERVENTION ON THE PROTECTION OF INDIVIDUALS OWING TO A FUNDAMENTAL RIGHTS' NARRATIVE}

Besides acknowledging the presence of the 'social' across a wide range of EU policies, a striking feature of recent developments is the way social questions are increasingly addressed through a fundamental rights' narrative and so, outside of the Social Policy Title. In this context, and contrary to that of the last

\footnotetext{
${ }^{51}$ A. Hinarejos, 'A Missed Opportunity: The Fundamental Rights Agency and the Euro Area Crisis', 22 European Law Journal (2016) p. 61 at p. 70.

${ }^{52}$ M.E. Salomon, 'Of austerity, human rights and international institutions', 21(4) European Law Journal (2015) Section IV.

${ }^{53}$ Zeitlin and Vanhercke, supra n. 38, p. 14-15.

${ }^{54}$ See suggestions in that direction by F. Vandenbroucke, 'The Idea of a European Social Europe: A Normative introduction', in Barnard et al., supra n. 10, p. 4-5.
} 
section, the consolidation of social values is often the central and explicit objective pursued. The lens is that of the protection of dignity across a broad range of social issues rather than a baseline of standards for workers' protection within the meaning of the traditional social acquis. Besides broadening the scope of $\mathrm{EU}$ intervention for the protection of individuals along the lines of paragraph 2 of Article 3(3) TEU, quoted in the introduction above, the emphasis placed on fundamental rights in the past few years has also allowed for regulatory innovation - i.e. the use of new legal tools - in what relates to the protection of individuals at EU level. Rights have been more firmly anchored in the EU constitutional framework, while the legislative instruments that give them shape is characterised by a broad tool kit that is largely unknown to EU social law and policy stricto sensu.

\section{Enhanced protection of individuals through fundamental rights}

The fundamental rights impetus has allowed the protection afforded by EU law to stretch to areas of social protection that had mostly remained within domestic competences until recently. Meanwhile, the fundamental rights narrative invites reflections on yet newer and complementary dimensions of the EU's human face. ${ }^{55}$

\section{EU anti-discrimination policy: employment and beyond}

As EU social policy was entering a phase of stagnation, EU anti-discrimination blossomed in the post-Amsterdam era after the insertion of what is today Article 19 TFEU. Importantly for our purpose, the said Article 19 TFEU is located outside of the Title of the TFEU on Social Policy. Possibly thanks to this special anchoring, the related wave of new legislation surfed on a powerful fundamental rights' narrative. Article 19 TFEU has been relied upon for the adoption of several anti-discrimination Directives to combat discrimination on grounds of race/ethnic origin, age, sexual orientation, disability and religion/belief as well as sex. The first two main Directives, the Racial Equality Directive ${ }^{56}$ and the Framework Employment Directive, ${ }^{57}$ were adopted very swiftly. This resulted from a broad mobilisation of various non-governmental organisations, from a political momentum created by reactions to the success of J. Haider in the Austrian elections as well as from a lively reflection on the role of fundamental right

\footnotetext{
${ }^{55}$ I am grateful to Claire Kilpatrick for suggesting that expression.

${ }^{56}$ Directive 2000/43 implementing the principle of equal treatment between persons irrespective of racial or ethnic origin (OJ L 180, 19.7.2000, p. 22-26).

${ }^{57}$ Directive 2000/78 establishing a general framework for equal treatment in employment and occupation (OJ L 303, 2.12.2000, p. 16-22).
} 
protection in the process of European integration. ${ }^{58}$ Besides broadening the scope of EU anti-discrimination law, the so-called 'Article 19 TFEU Directives' ${ }^{59}$ have also introduced innovative legal tools to tackle discrimination; this has in turn led to the modernisation of pre-existing EU sex equality law. ${ }^{60}$

In essence, this legislative framework is primarily intended to prohibit discrimination in employment and thus deals with questions that are at the core of a traditional approach to social policy, although viewed through the lens of human dignity. ${ }^{61}$ For instance, the EU anti-discrimination law regime largely impacts on the age balance of labour forces. ${ }^{62}$ Yet, this EU legislative framework also relates to aspects of people's social lives that go well beyond the classic realm of EU social policy. The prohibitions of sex and racial/ethnic origin discrimination also cover access to goods and services, ${ }^{63}$ including housing, and the latter also covers education. The Commission has, for instance, initiated early stages of infringement procedures in relation to the segregation of Roma children in school in selected member states. ${ }^{64}$ The EU anti-discrimination law framework thus makes it clear that EU intervention to combat social exclusion and discrimination, as mentioned in Article 3 TEU, is worth investigating outside of the traditional Social Policy Title.

\section{Towards a more holistic approach to the EU's duty to protect individuals?}

Related to this broadening of the range of social issues touched upon by EU intervention, recent years have been marked by a multiplication of pieces of

${ }^{58} \mathrm{See}$ V. Guiraudon, 'Construire une politique européenne de lutte contre les discriminations', 53 (11) Sociétés Contemporaines (2004) p. 23-24.

${ }^{59}$ See also Directive 2004/113 implementing the principle of equal treatment between men and women in the access to and supply of goods and services (OJ L 373, 21.12.2004, p. 37-43).

${ }^{60}$ Directive $2006 / 54$ on the implementation of the principle of equal opportunities and equal treatment of men and women in matters of employment and occupation (OJ L 204, 26.7.2006, p. 23-36).

${ }^{61}$ Critically exploring the distinction between social policy and anti-discrimination approaches: A. Somek, Engineering Equality: An Essay on European Antidiscrimination Law (Oxford University Press, 2011). I do not wish to engage in this discussion here; see the preliminary assumptions in the Introduction.

${ }^{62}$ See E. Dewhurst, 'The Development of EU Case-Law on Age Discrimination in Employment: "Will You Still Need Me? Will You Still Feed Me? When I'm Sixty-Four"', 19(4) European Law Journal (2013) p. 517.

${ }^{63}$ For an illustration of the relevance in the field of insurance protection see ECJ 1 March 2011, Case C-236/09, Association Belge des ConsommateursTest-Achats ASBL v Conseil des ministers, ECLI:EU: C:2011:100; and access to information on electricity services, see ECJ 16 July 2015, Case C-83/14, 'CHEZ Razpredelenie Bulgaria' AD v Komisia za zashtita ot diskriminatsia, ECLI:EU:C:2015:480.

${ }^{64}$ In particular, the Commission sent letters of formal notice under Art. 258 TFEU to the Czech Republic (25/09/2014, infringement number 20142174); Slovakia (29/04/2015, infringement number 20152025); and Hungary (26/05/2016, infringement number 20152206). 
legislation putting flesh on the bones of specific fundamental rights. This legislation invites us to further reflect on the protection afforded by EU law beyond the realm of employment as traditionally covered within the Social Policy Title. For instance, EU data protection law has blossomed in recent years owing to the rise of a powerful fundamental right rationale besides its internal market dimension. ${ }^{65}$ The right to data protection applies in the sphere of employment, ${ }^{66}$ and has further been heralded as a key component of people's social life. The very notion of personal data is understood as 'any information relating to an identified or identifiable natural person'; and an identifiable natural person is one 'who can be identified, directly or indirectly, in particular by reference to an identifier such as [...] [the] social identity of that natural person. ${ }^{, 67}$ The broad range of the protection afforded by EU law to individuals in that field is well illustrated by the Court's reasoning in Österreichischer Rundfunk ${ }^{68}$ that related to data on income for the purpose of publishing the names and income of employees of a broadcasting organisation governed by public law, as well as in Google Spain on processing of personal data carried out by the operator of a search. ${ }^{69}$

Similarly, the 'human' dimension of EU migration policy is taking an increasingly important place in debates on the ability of the EU to protect individuals. EU institutions have established a minimum floor of social rights for certain categories of third-country nationals on equal treatment rights of longterm residents' third country nationals in access to housing benefits, as illustrated by Kamberaj, ${ }^{70}$ and on access to a benefit for households having at least three minor children for the holder of a single work permit covered by EU law,

${ }^{65}$ O. Lynskey, The Foundations of EU Data Protection Law (Oxford University Press 2015) p. $62 \mathrm{ff}$.

${ }^{66}$ E.g. Art. 88 of Regulation $2016 / 679$ on the protection of natural persons with regard to the processing of personal data and on the free movement of such data, and repealing Directive 95/46 (OJ L 119, 4.5.2016, p. 1-88).

${ }^{67}$ Regulation $2016 / 679$ on the protection of natural persons with regard to the processing of personal data and on the free movement of such data (OJ L 119, 4.5.2016, p. 1-88) Art. 2(1).

${ }^{68}$ ECJ 20 May 2003, Joined Cases C-465/00, C-138/01 and C-139/01, Österreichischer Rundfunk, EU:C:2003:294, para. 42. In this respect, see H. Kranenborg, 'Article 8 - Protection of Personal Data', in S. Peers et al. (eds.), The EU Charter of Fundamental Rights: A Commentary (Oxford University Press 2014) p. 227. The scope of the main instrument on EU data protection is now defined in broad terms in Art. 2 of Regulation 2016/679, supra n. 68.

${ }^{69}$ ECJ 13 May 2014, Case C-131/12, Google Spain and Google, EU:C:2014:317, paras. 80-81 and 99.

${ }^{70}$ ECJ 3 May 2012, Case C-520/10, Servet Kamberaj v Istituto per l'Edilizia Sociale della Provincia autonoma di Bolzano (IPES), ECLI:EU:C:2012:233, para. 90. See further S. Peers, 'Case Note on Kamberaj', 50 CML Rev (2013) p. 529. See also ECJ 4 June 2015, Case C-579/13, P and S v Commissie Sociale Zekerheid Breda and College van Burgemeestder en Wethouders van de gemeente Amstelveen, ECLI:EU:C:2015:369. 
in Martinez Silva. ${ }^{71}$ Beyond this set of social rights for legally residing thirdcountry nationals, there are undeniable and major problems with the current handling of the migration crisis, be they located in the "EU-Turkish statement ${ }^{72}$ or in the conditions for the reception of asylum seekers on EU territory. ${ }^{73}$ These problems revolve around the (in)ability of the $\mathrm{EU}$ to ensure the protection of the fundamental right to dignity.

The challenges described above constitute many invitations to reflect on the role of the EU in promoting social justice and protection well beyond the narrow confines of the Social Policy Title TFEU. The prominent place that such topics have been taking on the EU's agenda over the past few years stresses the importance of looking beyond the Social Policy Title TFEU to critically reflect on the ability of the EU to protect against exclusion and discrimination. What can be the practical benefits of taking such a broad approach to the 'social' in EU law?

\section{Regulatory innovation flowing from fundamental rights law-making}

Approaching the question of the protection of individuals through a fundamental rights' narrative further allows us to re-think the techniques for shaping legal intervention in the field in two ways. Firstly, if the Court's restrictive approach to the 'Solidarity' Title of the Charter of Fundamental Rights of the EU can be contained within that Title, the fundamental rights' narrative may be relied upon through regulatory engineering to support a greater degree of protection of vulnerable individuals on the basis of other rights. Secondly, the fundamental rights' narrative has been a strong driving force for legislative innovation over recent years. The outcome of these processes can in turn provide useful perspectives for development if the provisions of the Social Policy Title was being reactivated.

\section{Engineering the constitutional protection of individuals}

The 'Solidarity' Title of the Charter - that matches closely the policy areas covered in the Social Policy Title of the TFEU - has been a source of disappointment for many. Nevertheless, the positioning of principles and rights addressing social

\footnotetext{
${ }^{71}$ E.g. ECJ 21 June 2017, Case C-449/16, Kerly Del Rosario Martinez Silva v Istituto nazionale della previdenza sociale (INPS) and Comune di Genova, ECLI:EU:C:2017:485, paras. 29-30.

${ }^{72}$ See ECJ, Case C-208/17 P, Appeal brought against the order of the General Court in Case T-192/16, NF v European Council (OJ C 231, 17.7.2017, p. 12-13), pending.

${ }^{73}$ E.g. see Amnesty International, 'Hotspot Italy: How EU's flagship approach leads to violations of refugee and migrant rights', 3 November 2016, available at <www.amnesty.org/en/documents/ eur30/5004/2016/en/ >, visited 28 December 2017.
} 
questions outside of the 'Solidarity' Title has actually allowed such displaced rights and principles to gain in strength. To start with, the reservations of the UK, Poland and the Czech Republic on the justiciability of the 'Solidarity' Title owing to Protocol $30^{74}$ as well as the possible effects that these may have on the recognition of 'general principles of $\mathrm{EU} \mathrm{law}^{\text {,75 }}$ in that field are not applicable outside of that title. As a consequence, other provisions of the Charter with implications for social protection are not covered by these reservations.

In line with the above, rights asserted outside of the 'Solidarity' Title have so far benefited from a more robust case law than the provisions of the said title. Since the ruling in Mangold, ${ }^{76}$ as subsequently confirmed, ${ }^{77}$ it is indeed established that the existence of secondary legislation giving specific expression to the fundamental right to non-discrimination on grounds of age allows EU law to have a direct impact on the outcome of an inter-personal dispute. ${ }^{78}$ Although not directly relied upon, Article $21 \mathrm{CFEU}$ explicitly prohibits discrimination on a set of grounds including those at hand in the relevant case law. This provision of the Charter thus seems to have been used as a (tacit) source of inspiration supporting the broadening of the possibility to invoke EU anti-discrimination directives. ${ }^{79}$

This case law illustrates the potential of discussing social questions outside of the strict social policy setting. The Court has been invited to consider several initiatives drawing parallels between EU anti-discrimination policy and other policies. A particularly interesting set of cases relates to the 'Solidarity' Title of the Charter as complemented by Directives belonging to the EU social acquis. Directive 2003/88, which was at stake in Dominguez, ${ }^{80}$

\footnotetext{
${ }^{74}$ Protocol 30 on the application of the said Title in the UK, Poland, Art. 2 and European Council Decision of 29/30 October 2009 on the application of Protocol 30 to the Czech Republic, Annex 1.

${ }^{75}$ See the case law on working time below.

${ }^{76}$ ECJ 22 November 2005, Case C-144/04, Werner Mangold v Rüdiger Helm [2005] ECR I-9981, paras. 74-76.

${ }^{77}$ Last confirmed, although in slightly different terms, in ECJ 19 April 2016, Case C-441/14, Dansk Industri (DI), acting on behalf of Ajos A/S v Estate of Karsten Eigil Rasmussen ECLI:EU: C:2016:278.

${ }^{78}$ See M. de Mol, 'The Novel Approach of the ECJ on the Horizontal Direct Effect of the EU Principle of Non-Discrimination: (Unbridled) Expansionism of EU law?', 18(1-2) MJECL (2011) p. 109, para IV.3.a.

${ }^{79}$ In subsequent cases, an explicit link was made between the general principle prohibiting discrimination on grounds of age and Art. 21(1) CFEU. E.g. ECJ 7 March 2014, Case C-176/12, Association de médiation sociale v Union locale des syndicats CGT, ECLI:EU:C:2014:2, para. 47.

${ }^{80}$ ECJ 24 January 2012, Case C-282/10, Maribel Dominguez v Centre informatique du Centre Ouest Atlantique and Préfet de la région Centre ECLI:EU:C:2012:33.
} 
and Fenoll, ${ }^{81}$ concerns certain aspects of the organisation of working time. ${ }^{82}$ Directive 2002/14, involved in the $A M S^{83}$ case, establishes a general framework for informing and consulting employees in the EU ('Information and Consultation Directive'). ${ }^{84}$ The similarity with Mangold case law in the field of age discrimination was the existence of an overlap between provisions of the Charter and provisions of the directives.

Yet, the Court declined to draw a parallel with the anti-discrimination instruments at hand in Mangold and subsequent case law. In Dominguez ${ }^{85}$ as well as in Fenoll, ${ }^{86}$ the Court cautiously avoided directly addressing the details of a possible parallel between annual paid leave and anti-discrimination. In contrast, in the $A M S$ case the Court explicitly distinguished the legal setting to which information and consultation of workers belongs from that of anti-discrimination. The Court noted that Article $27 \mathrm{CFEU}$ - on workers' right to information and consultation within the undertaking - must be given more specific expression in EU or national law. ${ }^{87} \mathrm{It}$ therefore cannot, as such, be invoked in a dispute to conclude that the national provision which is not in conformity with Information and Consultation Directive should be set aside. ${ }^{88}$ The weakness of Article 27 CFEU, adds the Court, cannot be palliated by considering that article in conjunction with the provisions of the said directive 'given that, since that article by itself does not suffice to confer on individuals a right which they may invoke as such, it could not be otherwise if it is considered in conjunction with that directive. ${ }^{89}$

This approach sharpens the distinction between the protection against antidiscrimination and the provisions in the 'Solidarity' Title, thus placing emphasis on the quality of the drafting of the said Title (as well as on the possible ambiguities created by Protocol 30). Now, if the Court's restricted reading of rights is limited to the 'Solidarity' Title indeed, fundamental rights' provisions outside of that Title are more likely to be interpreted for the benefits of individuals

\footnotetext{
${ }^{81}$ ECJ 26 March 2015, Case C-316/13, Gérard Fenoll v Centre d'aide par le travail La Jouvene' and Association de parents et d'amis de personnes handicapées mentales (APEI) d'Avignon ECLI:EU: C:2015:200.

${ }^{82}$ Directive 2003/88 concerning certain aspects of the organisation of working time (OJ L 299, 18.11.2003, p. 9-19).

${ }^{83}$ Association de médiation sociale $\mathrm{v}$ Union locale des syndicats CGT, supra $\mathrm{n} .80$.

${ }^{84}$ Directive 2002/14 establishing a general framework for informing and consulting employees in the European Community - Joint declaration of the European Parliament, the Council and the Commission on employee representation (OJ L 080, 23/03/2002, p. 29-34).

${ }^{85}$ See Dominguez, supra n. 81, para. 16 and M. de Mol, 'Dominguez: A deafening silence European Court of Justice', 8(2) EuConst (2012) p. 280 at p. 290-91.

${ }^{86}$ See Fenoll, supra n. 82, paras. 45-48.

${ }^{87}$ Association de médiation sociale $\mathrm{v}$ Union locale des syndicats CGT, supra n. 80, para. 45.

${ }^{88}$ Ibid., paras. 46-48.

${ }^{89}$ Ibid., para. 49.
} 
(although admittedly and importantly that may not always be the case). For instance, if one takes the holistic approach to individuals' protection sketched out in the past section, one could seek to rely on the Mangold case law to enhance the legal effects of the Data Protection Directive from $1995^{90}$ giving expression to the fundamental right to data protection. This case law could indeed prove most useful where alleged breaches of data protection law result from the behaviour of private entities in settings in which domestic law may not have adequately implemented the said directive. ${ }^{91}$

\section{Fundamental rights policies as a laboratory for regulatory innovation}

A related effect of reliance on a fundamental right narrative has been to feed into a new appetite for legislation that does not have an equivalent in the context of EU social policy stricto sensu to date. As pointed out above, the first generation of anti-discrimination Directives adopted on the basis of Article 19 TFEU were adopted remarkably quickly after the entry into force of the Amsterdam Treaty. Similarly, numerous legislative instruments with broad yet important social implications have been adopted in the context of EU migration and data protection policies, as noted already.

The very nature of EU intervention in these new fields may be a useful source of inspiration to revitalise the traditional EU social acquis. Indeed, the variety of stakeholders involved as well as the range of domestic laws affected by the broad social implications of such legislation illustrate new pathways for decision-making at EU level. For instance, the Article 19 TFEU Directives on non-discrimination have introduced a fairly sophisticated set of procedural provisions intended to support victims of discrimination, enhance the dissemination of information on the content of the directives, stimulate dialogue with social partners as well as nongovernmental organisations, facilitate litigation and enhance actual redress. ${ }^{92}$

Recent EU directives concerning the enforcement of the rights of EU migrant workers and their families, ${ }^{93}$ as well as those of posted workers, ${ }^{94}$ have initiated a

\footnotetext{
${ }^{90}$ Directive $95 / 46$ on the protection of individuals with regard to the processing of personal data and on the free movement of such data (OJ L 281, 23.11.1995, p. 31-50).

${ }^{91}$ The matter came up in Satamedia but the Court did not answer that aspect of the questions raised before it: ECJ 16 December 2008, Case C-73/07, Tietosuojavaltuutettu v Satakunnan Markkinapörssi Oy and Satamedia Oy ECLI:EU:C:2008:727, paras. 50-62. Admittedly, as the 1995 Data Protection Directive will be replaced by the 2016 Regulation and Art. 61(1) TFEU postLisbon may be capable of horizontal direct effect, the Mangold case law is becoming less relevant for this specific area of EU law.

${ }^{92}$ E.g. Racial Equality Directive, supra n. 57, Arts. 7-15.

${ }^{93}$ Directive 2014/54 on measures facilitating the exercise of rights conferred on workers in the context of freedom of movement for workers (OJ L 128, 30.4.2014, p. 8-14).

${ }^{94}$ Directive 2014/67 on the enforcement of Directive 96/71/EC concerning the posting of workers in the framework of the provision of services and amending Regulation (1024/2012 on administrative cooperation through the Internal Market Information System (OJ L 159, 28.5.2014, p. 11-31).
} 
process of cross-fertilisation allowing for the import of such procedural elements in EU free movement law, to the benefit of workers and posted workers in crossborder settings. They therefore relate to areas of EU law that are closely connected to core aspects of EU social policy stricto sensu and could provide a most valuable starting point for the upgrading of the social acquis. Furthermore, regulatory innovation does not stop with the anti-discrimination directives. Other areas of EU law providing a more holistic approach to the protection of individual rights also offer valuable perspectives. For example, the 2016 General Data Protection Regulation ${ }^{95}$ provides an innovative set of tools, such as the possibly to lodge complaints to independent supervisory authorities at national level. ${ }^{96}$ As for EU asylum law, an interesting aspect is that it explicitly provides for the involvement of an external organ, the United Nations High Commissioner for Refugees, in the monitoring of certain aspects of that area of law. ${ }^{97}$

The fundamental rights discourse has therefore allowed selected social questions to be directly and explicitly addressed through innovative legal techniques at EU level. Taken together, the constitutional and holistic approach described in the past sections have had important positive effects on the ability of individuals to rely on directives protecting them against discrimination in employment (among others) before domestic courts as well as more generally on the construction of a sophisticated set of tools intended to support a genuine implementation of protection grounded in EU law.

\section{Conclusions}

As noted in the introduction, the developments described above and labelled as 'positive' for the purpose of this article all have down sides. In the context of social law-making incidentally flowing from broader legal and policy developments at EU level, such as economic integration, the social dimension may often be instrumentalised and left behind. In the context of decisions to tackle social questions outside of social policy owing to a fundamental rights' discourse, developments are often located at the constitutional level, thereby creating a significant lack of flexibility and hindering politicisation; furthermore, the

\footnotetext{
${ }^{95}$ Regulation 2016/679, supra n. 68.

${ }^{96}$ Regulation 2016/679, Art. 77. See further O. Lynskey, 'The Role of Collective Actors in the Enforcement of the Right to Data Protection under EU Law', in E. Muir et al. (eds.), How EU Law Shapes Opportunities for Preliminary References on Fundamental Rights: Discrimination and other Examples (2017, Special Edition of the EUI Working Papers) forthcoming.

${ }^{97}$ E.g. Directive $2013 / 32$ on common procedures for granting and withdrawing international protection (OJ L 180, 29.6.2013, p. 60-95) Art. 29. See further E. Tsourdi, 'Enforcing Refugee Rights under EU Procedural Law: the Role of Collective Actors and UNCHR', in Muir et al., supra n. 97.
} 
dignitarian angle used to tackle these questions may not always allow the complex nature of social unbalances to be captured.

None of these sets of developments therefore compensate for the stagnation of the traditional EU social acquis. Yet, it may be beneficial for those interested in Social Europe to acknowledge the strengths of sparse positive developments across the broad spectrum of EU intervention. The process of European internal market and economic governance, as well as the driving forces behind EU law-making on fundamental rights, are characterised by a uniquely powerful and sophisticated web of legal tools. This creates important opportunities for advocacy and regulatory innovation of social policy that should not be neglected. 